University of New Hampshire

University of New Hampshire Scholars' Repository

10-1999

\title{
Bioavailability and trophic transfer of humic-bound copper from bacteria to zooplankton
}

Emile M. Lores

U.S. EPA

Jonathan Pennock

University of New Hampshire - Main Campus

Follow this and additional works at: https://scholars.unh.edu/smsoe

Part of the Bacteriology Commons, Environmental Microbiology and Microbial Ecology Commons, and the Marine Biology Commons

\section{Recommended Citation}

Lores, E. M. and J. R. Pennock. 1999. Bioavailability and trophic transfer of humic-bound copper from bacteria to zooplankton. Marine Ecology Progress Series 187:67-75.

This Article is brought to you for free and open access by the Institute for the Study of Earth, Oceans, and Space (EOS) at University of New Hampshire Scholars' Repository. It has been accepted for inclusion in School of Marine Science and Ocean Engineering by an authorized administrator of University of New Hampshire Scholars' Repository. For more information, please contact Scholarly.Communication@unh.edu. 


\title{
Bioavailability and trophic transfer of humic-bound copper from bacteria to zooplankton
}

\author{
Emile M. Lores ${ }^{1, *}$, Jonathan R. Pennock ${ }^{2}$ \\ ${ }^{1}$ U.S. Environmental Protection Agency, 1 Sabine Island Drive, Gulf Breeze, Florida 32561, USA \\ ${ }^{2}$ Dauphin Island Sea Lab, University of Alabama, PO Box 369-370, Dauphin Island, Alabama 36528, USA
}

\begin{abstract}
The effect of humic acid (HA) on uptake and transfer of $\mathrm{Cu}$ by selected marine organisms from the microbial loop was determined. Bacteria grown with and without $15 \mu \mathrm{g} \mathrm{Cu} \mathrm{l}^{-1}$ and with and without $10 \mathrm{mg}$ Suwannee River Humic Acid (SRHA) $\mathrm{l}^{-1}$ were fed to Uronema sp. The Uronema were subsequently fed to Acartia tonsa to determine the effect of humic acid on the uptake and transfer of $\mathrm{Cu}$ from bacteria to copepods. The presence of $10 \mathrm{mg}$ SRHA $\mathrm{l}^{-1}$ reduced $\mathrm{Cu}$ uptake in $\mathrm{A}$. tonsa by an average of $54 \%$ and significantly reduced the negative effects of $\mathrm{Cu}$ on reproductive success of $A$. tonsa. The percentage of the total $\mathrm{Cu}$ residues in $A$. tonsa resulting from feeding was estimated by exposing $A$. tonsa to the same conditions with and without pre-exposed Uronema as food. The results indicate that approximately $50 \%$ of the Cu residue is due to feeding. Thus, SRHA seems to affect $\mathrm{Cu}$ uptake in $\mathrm{A}$. tonsa through binding of free $\mathrm{Cu}$ in the water at the same rate as through the food chain. This study demonstrates the importance of complexation of metals by organic matter and trophic transfer processes for organisms critical to estuarine food webs.
\end{abstract}

KEY WORDS: Trophic transfer $\cdot$ Bioavailability $\cdot$ Humic acid $\cdot$ Zooplankton $\cdot$ Copper

\section{INTRODUCTION}

Macromolecules in dissolved organic matter (DOM) such as humic acid (HA) are known to adsorb onto the surfaces of microbes (Daniels 1980, Decho 1990). The fact that bacteria adsorb humic compounds (and therefore any compounds that may be complexed with the humics) onto their surfaces may be an important transport mechanism to higher trophic levels, such as bacterivores (e.g. ciliates) and zooplankton (e.g. copepods). Much research has been directed toward learning how HA effects the bioavailability of water-borne chemicals to higher aquatic organisms such as fish, molluscs and crustaceans (e.g. McCarthy et al. 1985, Alberts et al. 1989). Studies on the effect of HA on uptake have been inconsistent. Most of the existing research showed that binding to HA reduced the bioavailability of lipophilic compounds to organisms such as fish and amphipods in proportion to the fraction that was bound (e.g. Mc-

\footnotetext{
•E-mail: lores.emile@epa.gov
}

Carthy \& Jimenez 1985, Landrum et al. 1987, Kukkonen et al. 1990), indicating that the bound fraction was not available for uptake by these organisms. Other research, however, has shown either no effect on uptake or that the presence of HA increased the uptake of chemicals, especially metals (e.g. Steinberg et al. 1992, Pempkowiak et al. 1994, Penttinen et al. 1995).

Comparatively little is known about how $\mathrm{HA}$ effects bioavailability to aquatic organisms at the bottom of the food chain. The fact that many of the previous examples of increased uptake of chemicals in the presence of HA have occurred in filter-feeding organisms that ingest microbes suggests that bacterial adsorption may be an important factor. Bacterivores feeding on bacteria that have macromolecules adsorbed to their surfaces may be ingesting significantly higher quantities of such compounds than they would otherwise. Bacterivores may then pass these materials on to higher zooplankton such as copepods. Wyman \& O'Conner (1980) and McManus et al. (1983) demonstrated that feeding of PCB-contaminated phytoplankton to Acartia tonsa increased uptake of PCB. 
Few studies, if any, have evaluated the effect of HA on uptake and transfer of Cu by marine organisms of the microbial loop. Bacteria, ciliates and copepods are basic components of the microbial loop, a pathway that transfers carbon energy from dissolved organic matter to higher trophic levels (Azam et al. 1983, Sanders \& Wickham 1993). Copepods are significant grazers of phytoplankton during certain periods of the year, especially during phytoplankton blooms (e.g. Durbin et al. 1990, Mallin \& Pearl 1994, Dagg 1995). Ciliates are also a significant proportion of copepod diet during much of the year and may supply important nutritional components (e.g. Ohman \& Runge 1994, Ederington et al. 1995, Jonasdottir et al. 1995). The importance of these organisms in marine food webs has been well documented, and copepods in particular provide a basic link to larval fish (Runge 1988, Sanders \& Wickham 1993). If the adsorption of HA onto bacteria can carry significant amounts of adsorbed chemicals, then there could be a risk to higher organisms through the microbial loop. The use of ciliates and copepods in this study allowed the effects of HA on the uptake of Cu by bacteria to be linked with higher trophic levels, since ciliates and copepods are major links to higher trophic levels in the natural food chain (Stoecker \& Capuzzo 1990).

Copper is commonly found as a pollutant in marine/estuarine waters due to its uses in antifouling paints, in treatment of marine lumber, and many other sources. The United States Environmental Protection Agency has established a water quality criterion of $2.9 \mu \mathrm{g} \mathrm{Cu} \mathrm{l}^{-1}$ for marine waters (US EPA 1995). Sublethal effects in copepods have been demonstrated in the 1 to $10 \mu \mathrm{g} \mathrm{l}^{-1}$ range and reproductive effects are among the more sensitive of these sub-lethal indicators (Beers et al. 1977, Reeve et al. 1977, Sunda et al. 1990). The reported $\mathrm{LC}_{50}$ values for Acartia tonsa exposed to $\mathrm{Cu}$ were in the range of 17 to $40 \mathrm{\mu g} \mathrm{l}^{-1}$ (Sosnowski \& Gentile 1978, Sosnowski et al. 1979, Sunda et al. 1990).

This study examined microbial adsorption and food chain transfer of humic bound $\mathrm{Cu}$ in marine waters. Research concentrated on understanding the effects of $\mathrm{HA}$ on bioaccumulation and trophic transfer of $\mathrm{Cu}$ through several food chain components, including bacteria, ciliates, and the copepod Acartia tonsa.

\section{MATERIALS AND METHODS}

Descriptions and sources of materials, such as Suwannee River Humic Acid (SRHA), artificial seawater, and organisms Vibrio natriegens and Uronema sp., along with culture conditions and methods of preparation can be found in Lores et al. (1999). A description of statistical methods is also described therein. The concentration of SRHA used in all experiments was
$10 \mathrm{mg} \mathrm{l}^{-1}$. It was chosen because it is well characterized (Averett et al. 1989), it is an aquatic humic extract, and is commercially available. SRHA is approximately $50 \%$ carbon, and the concentration used in these experiments represents a DOC concentration of $5 \mathrm{mg} \mathrm{Cl}^{-1}$ This concentration was chosen to be high enough to cause measurable effects, but within the range of those found in estuaries (Moran et al. 1991). The choice to use artificial seawater was based on the desire to eliminate extraneous dissolved organics that may have been present in natural waters. The salinity of 16 was chosen for compatibility with the test organisms and to represent a median estuarine salinity. The concentration of $\mathrm{Cu}$ in these experiments was $15 \mu \mathrm{g} \mathrm{l}^{-1}$ and is below the $\mathrm{LC}_{50}$ concentration for Acartia tonsa of $17 \mu \mathrm{g}$ $\mathrm{Cu} \mathrm{l}^{-1}$. This $\mathrm{Cu}$ concentration is higher than marine water quality criteria set by the Environmental Protection Agency (1985), but the higher concentration was needed to cause a measurable effect.

Copepods Acartia tonsa were collected from local waters using a $153 \mu \mathrm{m}$ mesh $0.3 \mathrm{~m}$ diameter plankton net, then maintained in aquaria at ambient temperatures with sterilized filtered seawater from Santa Rosa Sound and fed a mixture of the unicellular algae Thalassiosira and Isochrysis prior to their use in the experiments. Only adult female or late stage copepedites were used in experiments. A. tonsa is found in estuarine waters throughout the United States. The use of $A$. tonsa in this study offered several advantages. 'The rapid rate of $\mathrm{Cu}$ uptake and egg production allowed both reproductive and bioavailability studies to be carried out in a matter of days. Their widespread and year-round availability was also advantageous.

Feeding/exposure experiments. To determine how humic binding affects bioavailability and food chain transfer, copepods were exposed to $\mathrm{Cu}$ and HA while being fed ciliates that were pre-exposed to the same conditions while feeding on bacteria. Three experiments were conducted, each consisting of 4 treatments and 3 replicates with and without $\mathrm{Cu}$ and $\mathrm{HA}$. The 4 treatments consisted of a seawater control (CTL), $10 \mathrm{mg} \mathrm{l}^{-1}$ humic acid control (HACTL), $15 \mu \mathrm{g} \mathrm{l}^{-1} \mathrm{Cu}$ exposure (CU) and a $15 \mathrm{\mu g} \mathrm{l}^{-1} \mathrm{Cu}$ exposure with $10 \mathrm{mg} \mathrm{l}^{-1}$ humic acid (CUHA). Cultures ( 1 l) were incubated in the dark in 21 Erlenmeyer flasks at $20 \pm 1^{\circ} \mathrm{C}$ and were shaken at $60 \mathrm{rpm}$. The first 2 experiments consisted of 3 phases: a microbial growth phase, a ciliate growth phase and a copepod feeding phase. Bacteria were cultured in the 4 treatments listed above, then ciliates were added to consume the bacteria. When the ciliates reached stationary phase, they were collected and fed to copepods under the same conditions. The first experiment used mixed bacterial assemblages that was grown to stationary phase before allowing ciliates to feed. The bacterial assemblages were obtained from 
cultures using $0.6 \mu \mathrm{m}$ filtrates of Santa Rosa Sound water used as an inoculate. The effects of $\mathrm{HA}$ and/or $\mathrm{Cu}$ on survival and reproduction (nauplii production) in copepods were also investigated in the first experiment. The second experiment used washed Vibrio natriegens, pre-exposed to treatment conditions for $24 \mathrm{~h}$, as a food source for the ciliates.

A third experiment was designed to determine how much Cu uptake was directly from water, allowing a determination of how much uptake was due to feeding. In the third experiment, Cu uptake was measured in copepods that were exposed to the same 4 treatments without ciliates as food to estimate the effect of SRHA on bioavailability of $\mathrm{Cu}$ through uptake pathways other than feeding.

Microbial growth phase. To start the first phase of the first feeding experiment, $100 \mathrm{ml}$ of inoculate was added to 21 Erlenmeyer flasks containing $900 \mathrm{ml}$ of artificial seawater, $25 \mathrm{mg}$ of yeast extract $\mathrm{l}^{-1}$, HA and/or $\mathrm{Cu}$ as required (flasks and all ingredients except innoculate had been heat sterilized and cooled). Microbial cell density was measured 3 times $\mathrm{d}^{-1}$. In the second experiment, an inoculate of Vibrio natriegens was used in place of the mixed inoculate; otherwise, conditions were the same.

Ciliate growth phase. After the microbial growth reached stationary phase, $100 \mathrm{ml}$ of ciliates Uronema $\mathrm{sp}$. at a density of approximately 10000 ciliates $\mathrm{ml}^{-1}$ were added to each microbial culture flask to begin the second phase. Samples for ciliate counts $(0.5$ to $2 \mathrm{ml})$ were collected 3 times $\mathrm{d}^{-1}$ and were preserved and counted as described in Lores et al. (1999). Ciliates were grown to stationary phase, collected by centrifugation $(300 \times g)$ and transferred to identical treatment flasks with 10 copepods in each, but without the yeast extract. A 50 to $100 \mathrm{ml}$ subsample of the ciliate culture was taken for analysis of $\mathrm{Cu}$ in the ciliates.

In the second experiment, $1 \mathrm{ml}$ of washed ciliates $\left(1 \times 10^{5}\right.$ ciliates $\left.\mathrm{ml}^{-1}\right)$ was added to $500 \mathrm{ml}$ flasks of washed Vibrio natriegens that had been pre-exposed to the treatment conditions for $24 \mathrm{~h}$. The ciliates were allowed to feed on the bacteria for approximately $24 \mathrm{~h}$ before a $50 \mathrm{ml}$ portion was taken for $\mathrm{Cu}$ analysis and a $100 \mathrm{ml}$ portion was concentrated and transferred to $2 \mathrm{l}$ Erlenmeyer flasks with $1 \mathrm{l}$ of treatment solution and 10 copepods. The copepods were allowed to feed on the ciliates for $24 \mathrm{~h}$ before being collected for analysis of $\mathrm{Cu}$ residues. The remaining ciliate culture was sampled again for $\mathrm{Cu}$ analysis $(50 \mathrm{ml})$ at $48 \mathrm{~h}$.

Copepod exposures. Ten copepods were selected for each treatment flask and held in approximately $100 \mathrm{ml}$ of artificial seawater for 2 to $4 \mathrm{~h}$. Copepods were transferred to treatment flasks and allowed to feed on ciliates for 1 to $3 \mathrm{~d}$ (56 h in the first experiment and $24 \mathrm{~h}$ in the second). After exposure, copepods were collected by straining the contents of each flask through a $44 \mu \mathrm{m}$ sieve. The contents of the sieve were washed into a petri dish with some of the strained water. Copepods were counted and survivors were then picked out with a glass pipette, washed with distilled water, and transferred to a plastic centrifuge tube for digestion and $\mathrm{Cu}$ analysis. The remaining solutions were preserved with rose bengal-formalin and nauplii were counted to determine reproductive success.

Copper analysis. For analysis of $\mathrm{Cu}$ residues in ciliates, a $50 \mathrm{ml}$ sample was centrifuged $(300 \times \mathrm{g}$ for $10 \mathrm{~min}$ ) in a plastic centrifuge tube which had been rinsed in $5 \% \mathrm{HCl}$. The supernatant was decanted while holding a glass rod over the pellet; the pellet was dried and digested in $100 \mu$ l of concentrated nitric acid at $90^{\circ} \mathrm{C}$. Live copepods collected at the end of each experiment were also dried and digested in $100 \mu \mathrm{l}$ of nitric acid. Only adult copepods alive at the end of the experiment were used for these analyses. Digested samples were diluted as necessary with distilled water, and duplicate $10 \mu \mathrm{l}$ aliquots were analyzed for $\mathrm{Cu}$ by Atomic Absorption Spectroscopy (AA) in a graphite furnace as described in Lores et al. (1999). The data was calculated on a per organism basis. Duplicate analyses were performed on all samples and standards and were repeated if the relative standard deviation was greater than $20 \%$. Samples with Cu concentrations higher than the highest standard were diluted and re-analyzed. A matrix spike was run on every set of samples and all matrix spike recoveries were greater than $80 \%$. Detection limit in the final solutions

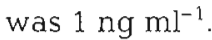

\section{RESULTS}

Microbial growth curves (mixed inoculate) from the first experiment are shown in Fig. 1. Initial background absorbance in treatments containing HA was higher than in treatments without $\mathrm{HA}$, and any decrease in absorbance due to loss of HA may have masked some growth; however, no significant differences in growth were apparent in any of the treatments.

At the end of the microbial growth phase, ciliates were added directly to the cultures, and the resulting Uronema sp. growth curves (Fig. 2) show growth on the mixed cultures for the first $36 \mathrm{~h}$. The remaining portion of these curves shows the ciliate density after they were transferred to copepod flasks as prey. Uronema growth was not significantly affected by $\mathrm{HA}$ in this experiment. The drop in ciliate density at $40 \mathrm{~h}$ was due to losses as the ciliates were collected and transferred to copepod feeding flasks. The Cu residues in these ciliates at the time they were transferred to the copepod flasks ranged from 0.05 picograms ciliate ${ }^{-1}$ in 


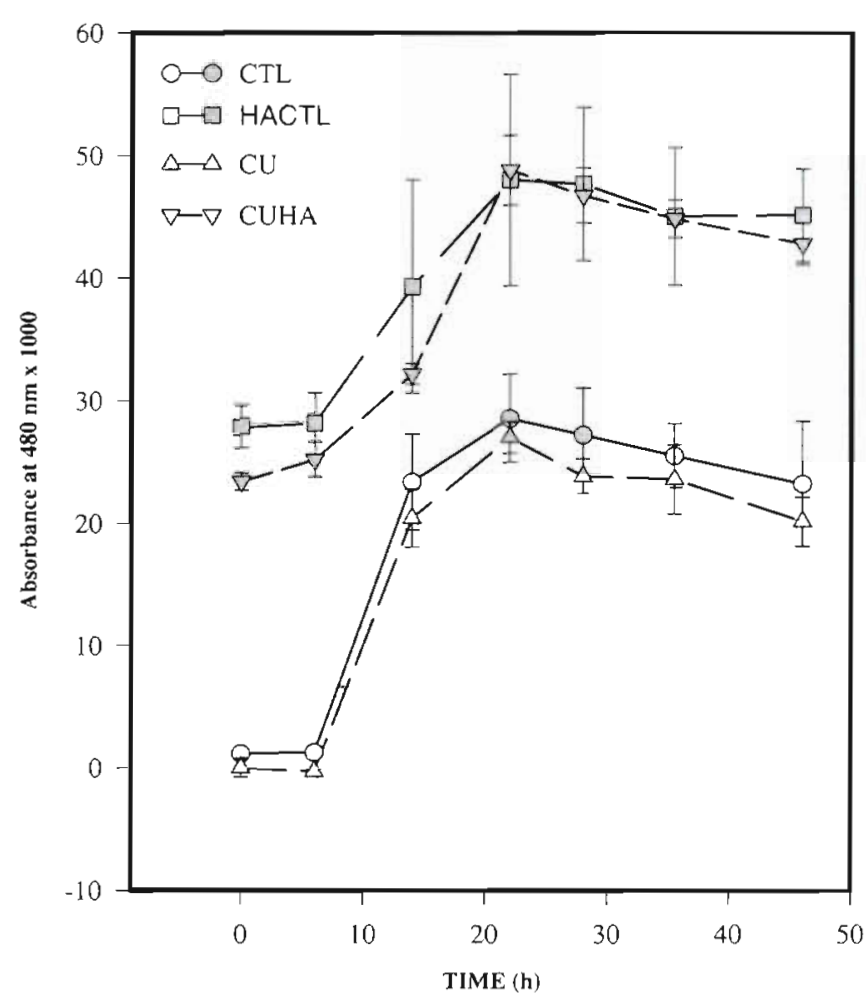

Fig. 1. Microbial growth curves estimated by optical density at $480 \mathrm{~nm}$ from experiment on effect of Suwannee River Humic Acid (SRHA) on transfer of Cu from bacteria to ciliates to copepods. $\mathrm{CTL}=$ control artificial seawater $\mathrm{HACTL}=$

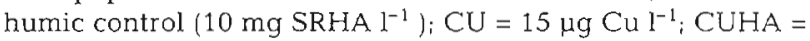

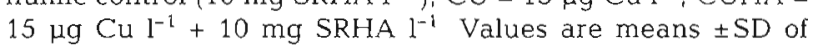
triplicates

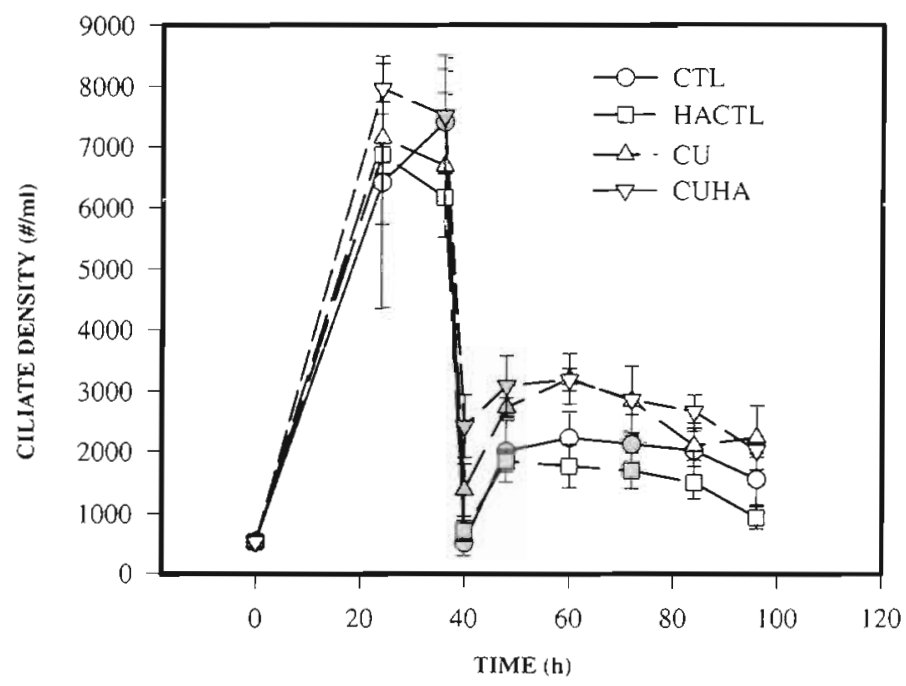

Fig. 2. Uronema sp. Ciliate growth curve from experiment on effect of Suwannee River Humic Acid (SRHA) on transfer of $\mathrm{Cu}$ from bacteria to ciliates to copepods. Treatments are the same as in Fig. 1. Values are means $\pm \mathrm{SD}$ of triplicates both controls to 0.14 and 0.29 picograms ciliate ${ }^{-1}$ in CUHA and CU treatments, respectively (Fig. 3). The difference between measured $\mathrm{Cu}$ residues ciliate ${ }^{-1}$ in the CU and CUHA treatments was statistically significant $(\alpha=0.05)$.

The $\mathrm{Cu}$ residues in copepods from this experiment ranged from 1.24 and $1.76 \mathrm{ng}$ copepod $^{-1}$ in HACTL and CTL, respectively, to 1.96 and $5.08 \mathrm{ng} \mathrm{copepod}^{-1}$ in CUHA and CU treatments, respectively (Fig. 3). There was a statistically significant difference $(\alpha=0.05)$ in $\mathrm{Cu}$ residues copepod ${ }^{-1}$ in the CU treatment and all other treatments, while the CUHA treatment was statistically different from HACTL, but not from CTL. In 1 of the samples from the CU treatment in the first experiment, there was only 1 copepod that survived; however, $\mathrm{Cu}$ residues were still detectable. In the other 2 CU samples, there were 5 and 6 copepods collected for analysis. In all other samples, at least 8 copepods were analyzed. In the first experiment (56 h), mean survival was $40 \%$ in the CU treatment and was greater than $87 \%$ in all other treatments (Fig. 4); however, there was no statistically significant differences $(\alpha=0.05)$. The mean number of nauplii collected from copepod flasks at the end of the 56 h experiment was significantly higher $(\alpha=0.05)$ in both controls and CUHA treatments compared with the total number of nauplii found in the CU treatment (Fig. 4).

In the second experiment, where copepods were exposed for only $24 \mathrm{~h}$ under the same conditions as in the first experiment, $\mathrm{Cu}$ residues in copepods were similar to results from the first experiment (Fig. 5). The $\mathrm{Cu}$ uptake was again lower in the presence of HA. Unlike the first experiment, copepod reproduction in this experiment was not significantly different, although the mean number of nauplii in the CU treatment was lower as in the first experiment. Statistical analyses of $\mathrm{Cu}$ residues in copepods from the first 2 experiments indicate that there are no statistical differences between experiments. Combining the results improved the level of significance (p-values), but did not change the overall significance of any of the pairwise comparisons.

In the second experiment, although ciliates were fed to copepods after $24 \mathrm{~h}$ exposure, ciliate exposure was continued for $48 \mathrm{~h}$. The total $\mathrm{Cu} \mathrm{m} \mathrm{m}^{-1}$ of ciliates over the $2 \mathrm{~d}$ exposure, where ciliates were feeding on washed Vibrio natriegens, increased on Day 2 compared to Day 1 (Fig. 6). The difference in total $\mathrm{Cu} \mathrm{m} \mathrm{m}^{-1}$ of ciliates between the CU and CUHA treatments was statistically significant $(\alpha \leq 0.05)$ on Days 1 and 2 . The Cu ciliate ${ }^{-1}$ in the CUHA treatment over the same $2 \mathrm{~d}$ exposure shows a continuous increase over the period (Fig. 6). Copper ciliate ${ }^{-1}$ was significantly higher in the CU treatment than in the CUHA treatment in ciliates collected on Day 2. 

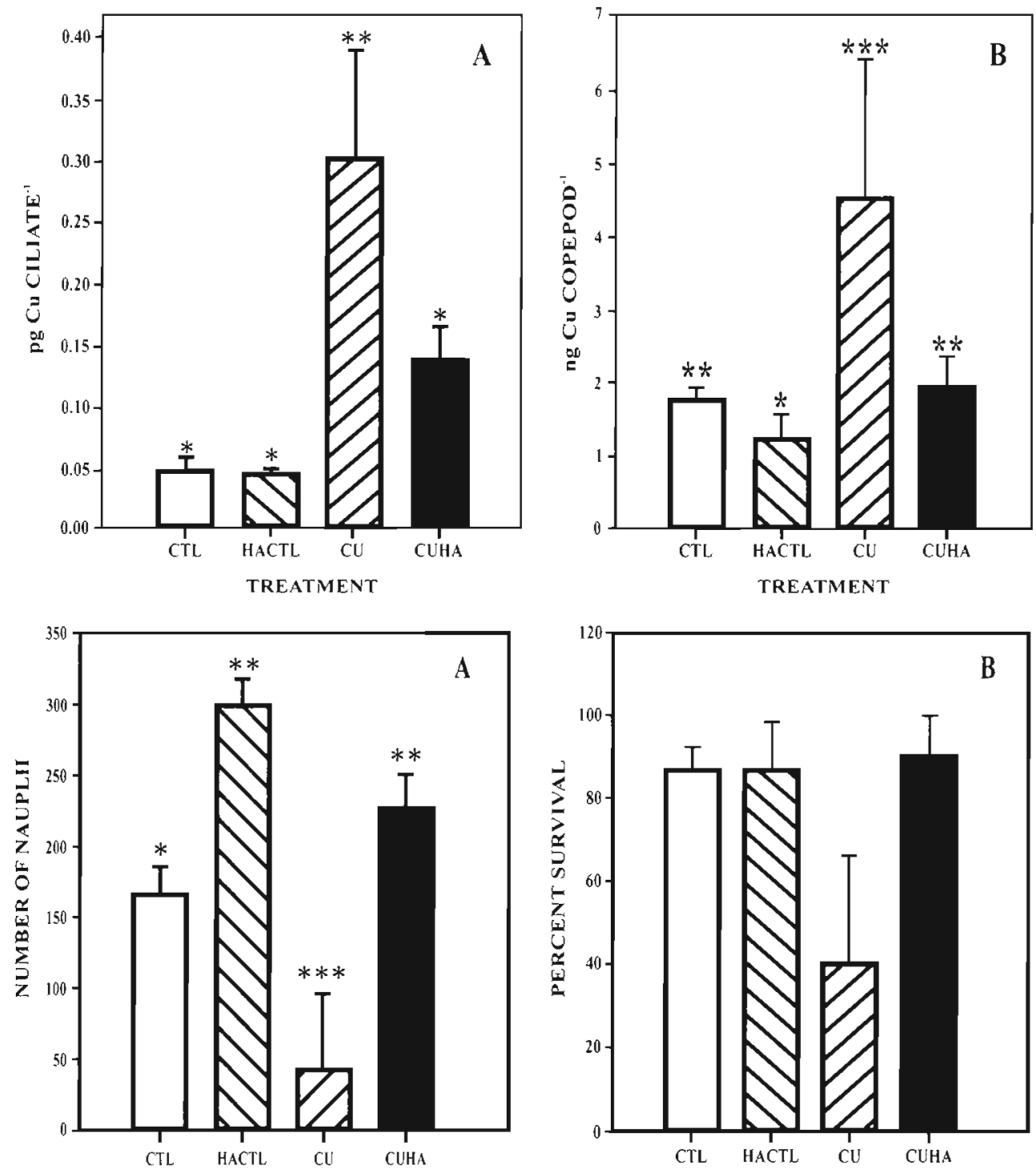

TREATMENT

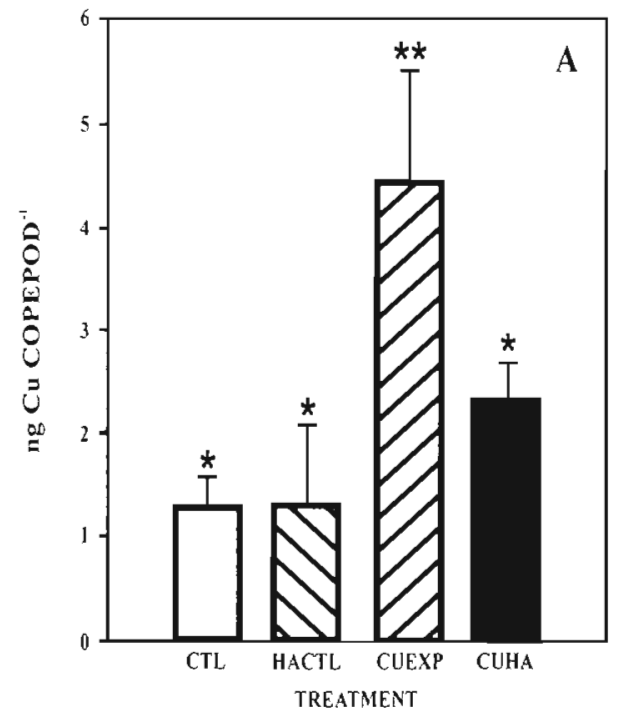

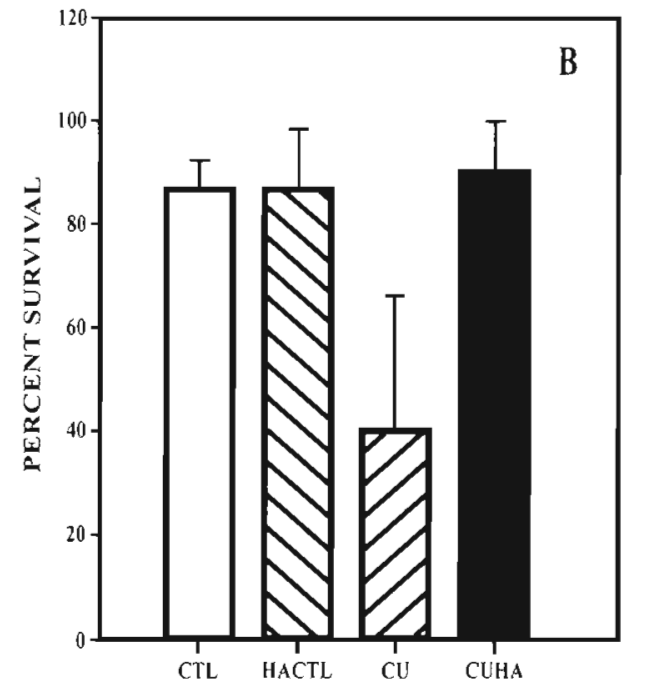

TREATMENT

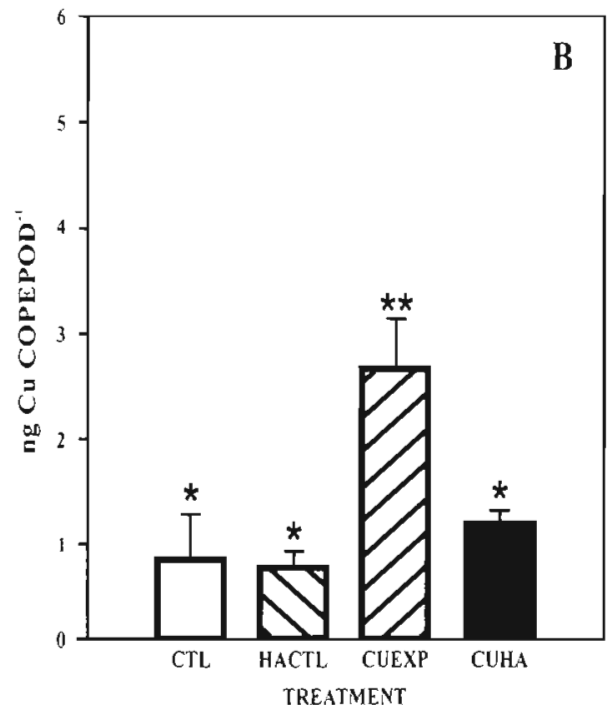

Fig. 3. Copper uptake by (A) ciliates after $24 \mathrm{~h}$ exposure while feeding on preexposed bacteria (B) copepods after $56 \mathrm{~h}$ exposure while feeding on ciliates. Treatments are the same as in Fig. 1. Values are means $\pm \mathrm{SD}$ of triplicates Difference in number of asterisks signifies statistical difference $(\alpha=0.05)$

Fig. 4. Acartia tonsa. (A) Reproduction and (B) survival of adult female after $56 \mathrm{~h}$ exposure in experiment on effects of Suwannee River Humic Acid on transfer of $\mathrm{Cu}$ from bacteria to ciliates to copepods. Treatments are the same as in Fig. 1. Values are means $\pm S D$ of triplicates. Difference in number of asterisks signifies statistical difference $(\alpha=0.05)$

Fig. 5. Copper levels in (A) copepods feeding on pre-exposed ciliates and (B) unfed copepods after $24 \mathrm{~h}$ exposure. Treatments are the same as in Fig. 1. Values are means $\pm S D$ of triplicates. Difference in number of asterisks signifies statistical difference $(\alpha=0.05)$ 

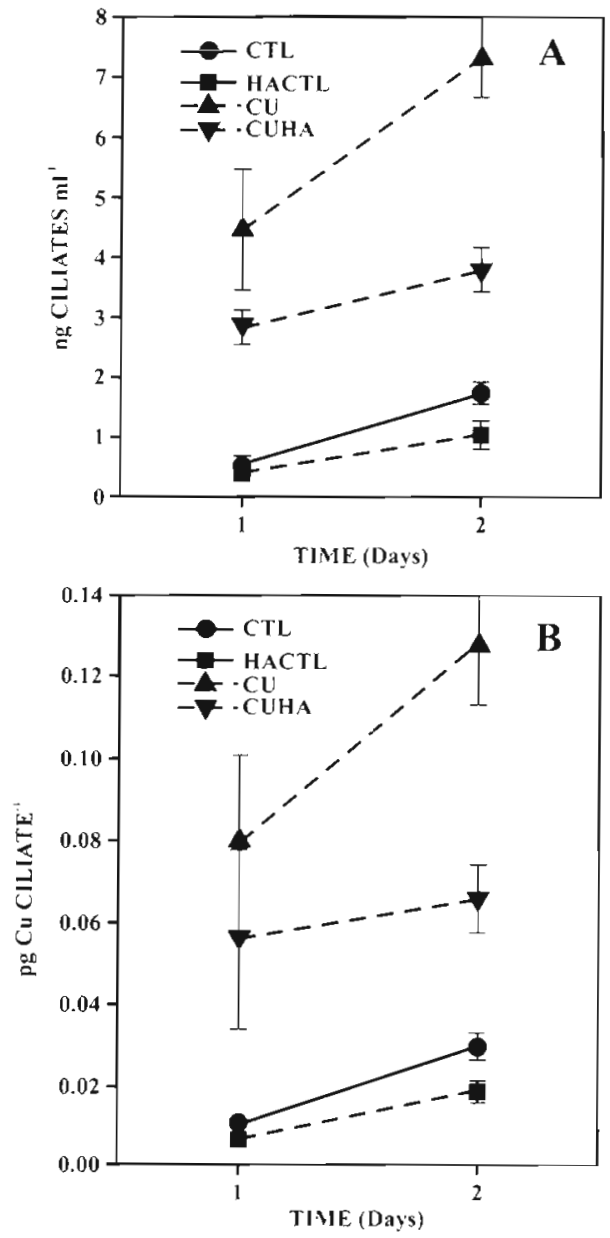

Fig. 6. Uronema sp. (A) Total $\mathrm{Cu} \mathrm{m}^{-1}$ of ciliate culture and (B) Cu uptake on a per ciliate basis over a $2 \mathrm{~d}$ exposure. Treatments are the same as in Fig. 1. Values are means $\pm \mathrm{SD}$ of triplicates

The overall $\mathrm{Cu}$ residues in copepods from the third experiment, in which copepods were exposed for $24 \mathrm{~h}$ without food (ciliates), were reduced when compared to the first 2 experiments where copepods were fed (Fig. 5). As in the first 2 experiments, Cu uptake was significantly reduced in the presence of HA $(\alpha=0.05)$. In copepods exposed to $\mathrm{Cu}$ without $\mathrm{HA}$, unfed copepods accumulated $2.6 \pm 0.5 \mathrm{ng}$ copepod ${ }^{-1}$, while unfed copepods that were exposed to $\mathrm{Cu}$ plus $\mathrm{HA}$ accumulated only $1.1 \pm 0.1 \mathrm{ng}$ copepod $^{-1}$.

\section{DISCUSSION}

The microbial growth curves (Fig. 1) are based on optical density measurements. The difference between the initial and final absorbance $\left(T_{f}\right)$ in the stationary phase can be used to estimate a net yield; however, it is possible that some of the HA may be utilized or adsorbed to cells, decreasing absorbance at the same time absorbance is increasing due to cell growth. Therefore, comparisons of the apparent yield between treatments with and without HA cannot be made, and though the differences in optical density are approximately the same, it is possible that the actual yield may be higher in the treatments with HA. Both treatments with HA do show a lag in growth during the log phase, but this too may be caused by binding of HA to cells. The $\mathrm{Cu}$ exposure levels in this experiment were not expected to have any effect on bacteria, and there did not seem to be any direct effect on microbial cultures caused by the $\mathrm{Cu}$ in this experiment, with the exception of a slightly more exaggerated lag in growth in the CUHA treatment. Copper residues in these mixed bacteria were not measured, but based on results with Vibrio natriegens (Lores et al. 1999), it is likely that the bacteria in the CUHA treatment contained less $\mathrm{Cu}$ to be transferred to their consumers, Uronema sp. in this case. The natural microbial mixtures in this experiment produced complex assemblages that were not reproducible. In addition, the actual cell density of a mixed culture cannot be estimated using optical density. Therefore, to reduce the complexity encountered in experiments with mixed cultures, further research with bacteria was restricted to $V$. natriegens.

The relative decrease in uptake of Cu by Uronema in CUHA treatments was approximately the same as in previous experiments (Lores et al. 1999) when ciliates were exposed to higher $\mathrm{Cu}$ levels. The decreased bioaccumulation of $\mathrm{Cu}$ by ciliates in the presence of HA suggests a decreased risk to ciliates and their consumers. The increased total ciliate $\mathrm{Cu}$ content (Fig. 6) in all treatments on Day 2 compared to Day 1 is probably due to movement of the Cu from the microbial pool (most of which is not collected by centrifugation at $300 \times g$ for $10 \mathrm{~min}$ ) to the ciliates. The increased uptake on Day 2 suggests that the response of the ciliate community as a whole may be slower than expected (days) relative to the doubling time of the population, which is only a few hours for Uronema.

In the first experiment, mean survival of copepods exposed to $\mathrm{Cu}$ was higher in the CUHA compared with the CU treatment (Fig. 4). The observed survival in the $\mathrm{CU}$ treatment is in agreement with the $\mathrm{LC}_{50}$ values reported by Sosnowski \& Gentile (1978). Survival was not significantly different in any of the treatments from the two $24 \mathrm{~h}$ experiments. The number of nauplii collected at the end of the first experiment was higher in both treatments with $\mathrm{HA}_{\text {; }}$ however, only the HACTL group was significantly higher than the CTL treatment. Reproduction was significantly lower in $\mathrm{CU}$ treatment and this group was statistically different from all other treatments. Similar effects from $\mathrm{Cu}$ on 
reproduction were seen by Reeve et al. (1977) who reported marked reduction of egg production in Acartia tonsa exposed to $\mathrm{Cu}$ at $20 \mu \mathrm{g}^{-1}$ from the first day and suggested that exposure to levels as low as $5 \mu \mathrm{g} \mathrm{l^{-1 }}$ can have reproductive effects over longer terms. Sunda et al. (1990) also investigated the bioavailability of complexed Cu to $A$. tonsa (using EDTA and NTA as complexing agents) and found that the complexation detoxified $\mathrm{Cu}$ and increased larval survival. In the second experiment, copepods were exposed to $\mathrm{Cu}$ for only $24 \mathrm{~h}$ and significant differences in survival and reproduction did not develop. There was a decrease in reproduction in the $\mathrm{CU}$ treatment as before, but the lack of a statistical difference in this case was probably related to the time of exposure.

In the first 2 experiments, the presence of SRHA reduced $\mathrm{Cu}$ uptake in copepods by 61 and $48 \%$, respectively. In the third experiment, SRHA reduced $\mathrm{Cu}$ uptake in copepods by $57 \%$ in the absence of food. The humic binding measurements in Lores \& Pennock (1998) suggest that approximately 60 to $80 \%$ of the $\mathrm{Cu}$ was bound to SRHA under the conditions similar to these experiments. However, $\mathrm{pH}$ was not measured in these experiments and small changes can significantly affect binding of $\mathrm{Cu}$ to $\mathrm{HA}$. If the bound $\mathrm{Cu}$ was closer to $60 \%$, these results suggest that little, if any, of the CuHA complex is available to copepods. However, if the bound $\mathrm{Cu}$ was near $80 \%$, as was found when $\mathrm{pH}$ was maintained at 7.0 , these results suggest that a small portion of the CuHA complex may be available

The consistency of the $\mathrm{Cu}$ copepod $^{-1}$ value suggests that measurement of individual copepod body burdens may be a useful indicator of environmental exposure. The fact that there seems to be little difference in body burden at 24 h compared with 56 h (Figs. 3B \& 5A) suggests that they rapidly reach steady state with their environment. More measurements are needed to determine the relationship between copper concentration and uptake, and to accurately correlate effects with $\mathrm{Cu}$ body burden in copepods. If established, such relationships could be used to improve ecosystem risk assessment since copepods appear to accumulate $\mathrm{Cu}$ rapidly, but do not accumulate the HA-complexed $\mathrm{Cu}$

Combined, the results from these experiments show the effects of feeding and HA on $\mathrm{Cu}$ accumulation and Fig. 7 provides an overall summary of the conditions and uptake of $\mathrm{Cu}$ by the organisms (that is assuming a $50 \%$ binding to $\mathrm{HA}$ ). In copepods exposed $24 \mathrm{~h}$ to $\mathrm{Cu}$ without HA, copepods that were not fed ciliates obtained approximately $40 \%$ less $\mathrm{Cu}$ than fed copepods. In copepods that were exposed to $\mathrm{Cu}$ plus HA, the unfed copepods accumulated approximately $50 \%$ less $\mathrm{Cu}$ than fed copepods. The higher $\mathrm{Cu}$ residues in fed copepods compared to unfed copepods suggest that the copepods are getting a significant amount of $\mathrm{Cu}$ through the feeding process, although it is possible that the uptake rate is just slower in unfed copepods. Reinfelder \& Fisher (1991) suggested that copepods assimilate only the soluble fraction of their food. The fact that in the CUHA treatment unfed accumulated less $\mathrm{Cu}$ on a percentage basis suggests that those copepods are getting more through the feeding process and that, possibly, the ciliates from the CUHA treatment are converting $\mathrm{Cu}$ to a more available form.

It is possible to calculate the $\mathrm{Cu} /$ carbon ratio in these organisms based on literature carbon values for each organism. If we assume that $40 \%$ of the Cu was associated with bacteria in the CU treatment and $15 \%$ associated with the bacteria in the CUHA treatment (Lores et al. 1999), then based on the Vibrio narreigens cell carbon content of $0.2 \mathrm{pg}$ in stationary phase (Ohman \& Snyder 1991) and cell density of $3 \times 10^{7} \mathrm{ml}^{-1}$, the

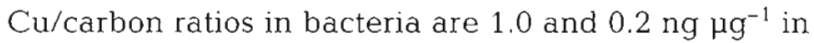
CU and CUHA treatments, respectively. For Uronema sp., based on a cell carbon of $0.31 \mathrm{ng}$, the ratios are 0.93 and $0.45 \mathrm{ng} \mathrm{gg}^{-1}$, respectively. And for Acartia

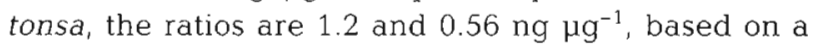
carbon content of $4.1 \mu \mathrm{g} \mathrm{C}$ copepod $^{-1}$ (Thompson et al. 1994). The values for the CU treatments are relatively constant, but the ratios seem to increase in the CUHA treatments, especially at the ciliate level, supporting the idea that the ciliates may be converting the CuHA complex into a more available form.

In all these experiments, Cu residues in ciliates and copepods in the CUHA treatment were significantly lower compared to the CU treatment. Thus, HA significantly reduced the bioavailability of $\mathrm{Cu}$ to these ciliates and copepods. However, some experiments suggest that ciliates may have active biological processes
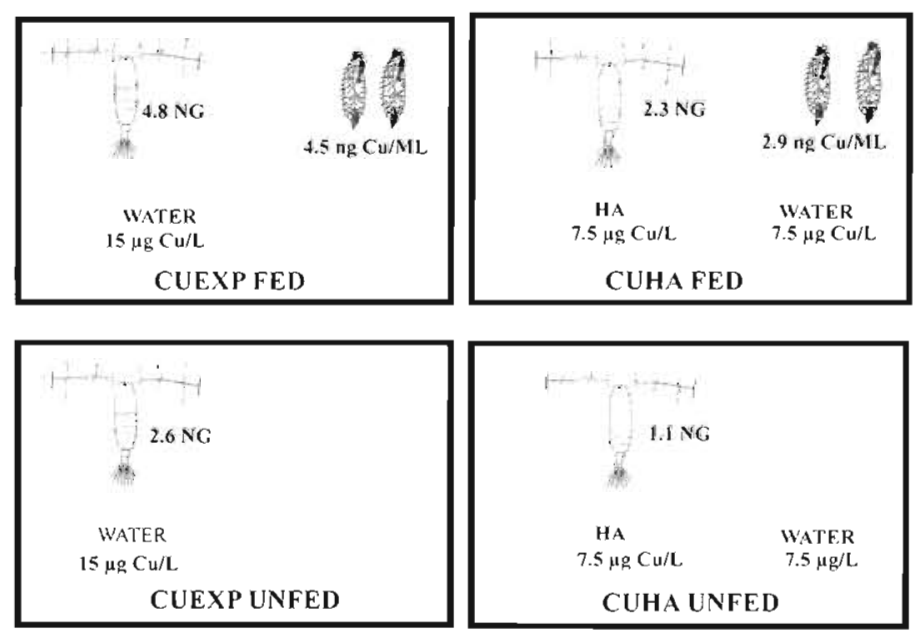

Fig. 7. Acartia tonsa and Uronema sp. Overall summary comparison of Cu uptake and conditions in experiments 
that counteract the sequestration of $\mathrm{Cu}$ by SRHA. In Lores et al. (1999), uptake of $\mathrm{Cu}$ by a different ciliate, Pleuronema sp., was not reduced by HA. It is possible that organisms more adept at utilizing HA (such as flagellates or specific bacteria) may be at risk when toxic chemicals are adsorbed to HA. More experiments are needed to fully understand the interactions between various organisms of the microbial loop, their growth phases and binding of metals to HA.

From an overall perspective, each component of an ecosystem will compete for resources within the ecosystem, even xenobiotics. Many of the processes involved in this competition are passive physical and chemical processes such as physical transport and binding of chemicals to living and non-living components. Earlier experiments showed the binding affinity of SRHA for Cu can change dramatically depending on the $\mathrm{pH}$ and salinity of the water (Lores \& Pennock 1998). Biological processes such as feeding, excretion, and population dynamics can be equally important. The microbial loop is an important component of estuarine and marine food webs. Most of the primary productivity of these waters goes through at least part of the microbial loop before it can be assimilated by larger organisms.

HA reduced $\mathrm{Cu}$ uptake by approximately half and improved survival and reproduction in copepods. The reproductive effects seen here and by others suggest that levels of Cu below the $15 \mu \mathrm{g} \mathrm{l}^{-1}$ can have dramatic effects on these organisms at the population level. Copper is listed as one of the top 10 pollutants in the estuarine waters and sediments of the Gulf of Mexico (US EPA 1995) and has the potential to cause dramatic shifts in the population of these important organisms, especially in the absence of organic complexing agents such as HA. The major sources of HA in estuaries are the forested wetlands along rivers and salt marshes around estuaries. These wetlands, the sources of HA, can provide protection from the adverse impact of environmental pollutants in areas far removed from the wetlands.

Acknowledgements. The authors would like the thank this journal's reviewers for their insightful and constructive reviews. We would also like to thank Stephen Embry for graphic support and Richard A. Snyder for help in obtaining and culturing bacteria and ciliates.

\section{LITERATURE CITED}

Alberts JJ, Filip Z, Leversee GJ (1989) Interaction of estuarine organic matter with copper and benzo(a)pyrene. Mar Chem 28:77-87

Averett RC, Leenher JA, McKnight DM, Thorn KA (1989) Humic substances in the Suwannee River, Georgia: interactions, properties and proposed structures. United States Geological Survey, Denver, Colorado
Azam F, Fenchel T, Field JG, Gray JS, Meyer-Reil LA, Thingstad F (1983) The ecological role of water-column microbes in the sea. Mar Ecol Prog Ser 10:257-263

Beers JR, Stewart GL, Hoskins KD (1977) Dynamics of microzooplankton populations treated with copper: controlled ecosystem pollution experiment. Bull Mar Sci 27(1):66-79

Dagg MJ (1995) Copepod grazing and the fate of phytoplankton in the northern Gulf of Mexico. Cont Shelf Res 15: $1303-1317$

Daniels SL (1980) Mechanisms involved in sorption of microorganisms to solid surfaces. In: Britton G, Marshall KC (eds) Adsorption of microorganisms to surfaces. John Wiley \& Son, New York

Decho AW (1990) Microbial exopolymer secretions in ocean environments: their role(s) in food webs and marine processes. Oceanogr Mar Biol Annu Rev 28:73-153

Durbin AG, Durbin EG, Wlodarczyk E (1990) Diel feeding behavior in the marine copepod Acartia tonsa in relation to food availability. Mar Ecol Prog Ser 68:23-45

Ederington MC, McManus GB, Harvey HR (1995) Trophic transfer of fatty acids, sterols, and a triterpenoid alcohol between bacteria, a ciliate, and the copepod Acartia tonsa. Limnol Oceanog 40:860-867

Jonasdottir SH, Fields D, Pantoja S (1995) Copepod egg production in Long Island Sound, USA, as a function of the chemical composition of seston. Mar Ecol Prog Ser 119: $87-98$

Kukkonen J, McCarthy JF, Oikari A (1990) Binding and bioavailability of organic micropollutants in natural waters effects of the quality and quantity of dissolved organic material. American Chemical Society, Boston, MA

Landrum PF, Nihart SR, Eadie BJ, Herche LR (1987) Reduction in bioavailability of organic contaminants to the amphipod Pontoporeia hoyi by dissolved organic matter of sediment interstitial waters. Environ Toxicol Chem 6: $11-20$

Lores EM, Pennock JR (1998) The effect of salinity on binding of $\mathrm{Cd}, \mathrm{Cr}, \mathrm{Cu}$ and $\mathrm{Zn}$ to dissolved organic matter. Chemosphere 37:861-874

Lores EM, Snyder RA, Pennock JR (1999) The effect of humic acid on uptake/adsorption of copper by a marine bacterium and two marine ciliates. Chemosphere 38:293-310

Mallin MA, Pearl HW (1994) Planktonic trophic transfer in an estuary: seasonal, diel, and community structure effects. Ecology 75:2168-2184

McCarthy JF, Jimenez BD (1985) Reduction in bioavailability to bluegills of polycyclic aromatic hydrocarbons bound to dissolved humic material. Environ Sci Technol 4:511-521

McCarthy JF, Jimenez BD, Barbee T (1985) Effect of dissolved humic material on accumulation of polycyclic aromatic hydrocarbons: structure-activity relationships. Aquat Toxicol 7:15-24

McManus GB, Wyman KD, Peterson WT, Wurster CF (1983) Factors affecting the elimination of PCBs in the marine copepod Acartia tonsa. Esutar Coast Shelf Sci 17:421-430

Moran MA, Pomeroy LR, Sheppard ES, Atkinson LP, Hodson RE (1991) Distribution of terrestrially derived organic matter on the southeastern U.S. continental shelf. Limnol Oceanogr 36:1134-1149

Ohman MD, Runge JA (1994) Sustained fecundity when phytoplankton resources are in short supply: omnivory by Calanus finmarchicus in the Gulf of St. Lawrence. Limnol Oceanogr 39:21-36

Ohman MD, Snyder RA (1991) Growth kinetics of the omnivorous oligotrich ciliate Strombidium $\mathrm{sp}$. Limnol Oceanogr 36:922-935

Pempkowiak J, Kozuch J, Southon T (1994) The influence of 
structural features of marine humic substances on the accumulation rates of cadmium by a blue mussel Mytilus edulis. Environ Int 20:391-395

Penttinen S, Kukkonen J, Oikari A (1995) The kinetics of cadmium in Daphnia magna as affected by humic substances and water hardness. Ecotoxicol Environ Saf 30: $72-76$

Reeve MR, Walter MA, Darcey K, Ikeda T (1977) Evaluation of potential indicators of sub-lethal toxic stress on marine zooplankton (feeding, fecundity, respiration, and excretion): controlled ecosystem pollution experiment. Bull Mar Sci 27:105-113

Reinfelder JR, Fisher NS (1991) The assimilation of elements ingested by marine copepods. Sci 251:794-796

Runge JA (1988) Should we expect a relationship between primary production and fisheries? The role of copepod dynamics as a filter of trophic variability. Hydrobiologia 167/168:61-71

Sanders RW, Wickham SA (1993) Planktonic protozoa and metazoa: predation, food quality and population control. Mar Microb Food Webs 7:197-223

Sosnowski SL, Gentile JH (1978) Toxilogical comparison of natural and cultured populations of Acartia tonsa to cadmium, copper, and mercury. J Fish Res Board Can 35:1366-1369

Sosnowski SL, Germond DJ, Gentile JH (1979) The effect of nutrition on the response of field populations of the

Editorial responsibility: Jennifer Purcell (Contributing Editor), Cambridge, Maryland, USA calanoid copepod Acartia tonsa to copper. Water Res 13:449-452

Steinberg CE, Strum A, Kelbel J, Lee SK, Hertkorn N, Freitag D, Kettrup AA (1992) Changes of acute toxicity of organic chemicals to Daphnia magna in the presence of dissolved humic material (DHM). Acta Hydrochim Hydrobiol 20: $326-332$

Stoecker DK, Capuzzo JM (1990) Predation on protozoa: its importance to zooplankton. J Plankton Res 12:891-908

Sunda WG, Tester PA, Huntsman SA (1990) Toxicity of trace metals to Acartia tonsa in the Elizabeth River and Southern Chesapeake Bay. Estuar Coast Shelf Sci 30: $207-221$

Thompson AM, Durbin EG, Durbin AG (1994) Seasonal changes in maximum ingestion rate of Acartia tonsa in Narragansett Bay, Rhode Island, USA. Mar Ecol Prog Ser 108:91-105

US EPA (1985) Water Quality Criteria. Federal Register Part II. United States Environmental Protection Agency. Washington DC, Federal Register. Vol 50:30784-30796

US EPA, NDPD (1995) Toxics Release Inventory System (TRIS). RTP, NC 27711, TSSMS Office (MS-346) 70 Alexander Dr, Bidg 4501

Wyman KD, O'Conner HB (1980) Implications of short-term PCB uptake by small estuarine copepods (genus Acartia) from PCB-contaminated water, inorganic sediments and phytoplankton. Estuar Coast Mar Sci 11:121-131

Submitted: September 18, 1998; Accepted: February 3, 1999 Proofs received from author(s): October 7,1999 